\title{
Evaluation of Doses of Radiation Due To Natural Radioactivity in Wheat As Animal Feed In the Surrounding Of the City Of Skopje (Macedonia)
}

\author{
Angeleska Aleksandra ${ }^{1}$, , Dimitrieska Stojkovik Elizabeta, Crceva Nikolovska \\ Radmila ${ }^{1}$, Hajrulai-Musliu-Zehra ${ }^{1}$, Dimzovska Biljana ${ }^{1}$, Uzunov Riste $^{1}$, \\ Jankuloski Dean ${ }^{1}$ \\ ${ }^{I}$ Food Institute, Faculty of Veterinary Medicine Skopje
}

\section{INTRODUCTION}

Soil is the first link of the ecological chain soil-food-animals-human, and for this reason it has an important role in the distribution and transfer of radionuclides in fodder, which would mean that the information about the radioactive contamination of the soil and the crops are a foundation that later on all criteria and norms of radiation safety rest on. The radioactive contamination of plants is formed with dynamic continuous common action of the atmosphere, the pedosphere and the hydrosphere. From the indicated fields of life, the influence of the pedosphere is dominant, considering that the main part of the minerals which make the plant body, originate from the soil. Therefore, primarily the physical-chemical characteristics of the soil are the main parameters which determine the quantity of accumulated radioactive substances in the plant organs. Some plants are capable to incorporate large amounts of radioactive substances in their tissues without visible and provable changes, however their consumption can cause serious impairments and diseases in the human organisms and the human. Of course, it may have a negative impact on the growth and development of plants if it is a matter of a stronger intensity of radioactive radiation. The radioactive contamination of the organs and the body tissues of animal organisms basically depends on the level of contamination of the food they consume, and to a less extent it depends on drinking water and inhalation. Assessments [1]. The natural radionuclides by means of migration come from the soil to the crops and contribute for total radiation burden in the population. Considering the fact that they can cause undesired effects on the human organism, it is necessary to determine the content of radionuclides in the surrounding, and on the basis of the obtained results the dose which the human receives should be calculated. However, it turned out that the understanding of the behavior of the natural radionuclides in the environment is very important, because such information can be used as the related parameter values for radiological assessments [2]. For this reason, the assessment of the dose of gamma radiation from natural sources is very important because the natural radiation mostly contributes for the external dose in the world population [3]. The goal of this study was focused on investigation of the radioactivity in wheat, and presence of natural radionuclides, and on the basis of the specific activity of the crops, we will calculate the dose which the human receives if the person consumes the examined crops.

\section{MATERIALS AND METHODS}

\subsection{Sampling}

The wheat samples were collected in 2016 from different locations in the surrounding of the city of Skopje. The sampling was performed so that 3 samples were taken from every location, which is in accordance with the recommendations from IAEA [4], whereby the number of samples should be between 2-3. All samples were thoroughly cleaned. Attention was paid to the micro-location, it should be a flat terrain, whereby the consequences for eventual horizontal translocation of radionuclides are excluded. The collected samples were carefully cleaned, placed on a foundation and grinded to a previously determined size of particles according to the analytical requirements and in the end they passed through a sieve. The homogenized samples were packed in plastic containers which had the same geometry as the one for the reference materials which were used for calibration of the measuring equipment.

\subsection{Instrument}

The samples are measured on an instrument - gamma spectrometer (Canberra Packard) with highpurity germanium detector. The measurement was performed in containers which were hermetically sealed so that ${ }^{222} \mathrm{Rn}$ produced from decay of ${ }^{226} \mathrm{Ra}$ will not result in gas leak. After the provision of time balance between the successors of ${ }^{238} \mathrm{U}$ and ${ }^{232} \mathrm{Th}$ series $(21$ days), these sealed samples were prepared for an analysis. The obtained spectra from the measurement were analyzed by using the program GENIE 2000. The specific activity of ${ }^{226} \mathrm{Ra}$ is calculated for energy line on $186,1(\mathrm{keV})$ and ${ }^{232} \mathrm{Th}$ through its descendant of decay ${ }^{228} \mathrm{As}$ (second in 
the decayed sequence), that is, through its three gamma decay energy lines which occur on 338,4; 911,07 and $968,9(\mathrm{keV})$. The activities of ${ }^{40} \mathrm{~K}$ were determined from its $\gamma$-line from $1460 \mathrm{keV}$. The interval of the time for calculation (counting) was 65.000 seconds. The natural spectrum was recorded immediately after or before the calculation of the sample.

\subsection{Specific activity}

\subsection{Rate of absorbed dose in the air (D)}

The natural decay of radionuclides in the soil is one of the main sources of the human exposure to radiation. This level of radiation is different depending on the content of minerals and radioactive elements of each region. The dose of gamma radiation which is due to natural radioactive contents of the soil is important for the population in the area where they live. The rate of absorbed does in the air for the radionuclides with a height of 1 meter above the ground surface was calculated on the basis of the instructions provided below [5].

$$
\mathrm{D}(\mathrm{nGy} / \mathrm{h})=0.462 \mathrm{~A}_{\mathrm{Ra}}+0.604 \mathrm{~A}_{\mathrm{Th}}+0.042 \mathrm{~A}_{\mathrm{k}}
$$

Where $A_{R a}, A_{K}$ and $A_{T h}$ accordingly are the average concentrations of activity of ${ }^{226} \mathrm{Ra},{ }^{40} \mathrm{~K}$ and ${ }^{232} \mathrm{Th}$ in regard to $\mathrm{Bq} / \mathrm{kg}$.

\subsection{External and internal danger index}

In order to assess the equivalent average of annual effective dose imposed to the residents of each area, the external danger index was calculated for soil samples. [6]

$$
\mathrm{H}_{\mathrm{eks}}=\mathrm{A}_{\mathrm{Ra}} / 370+\mathrm{A}_{\mathrm{Th}} / 259+\mathrm{A}_{\mathrm{k}} / 4810
$$

$\mathrm{A}_{\text {Ra }}, \mathrm{A}_{\mathrm{Th}}, \mathrm{A}_{\mathrm{k}-}$ specific activities $(\mathrm{Bq} / \mathrm{kg}),{ }^{226} \mathrm{Ra}^{232} \mathrm{Th}$ and ${ }^{40} \mathrm{~K}$, prespectively. The maximum value of $H_{\mathrm{ex}}$ equal to one corresponds to the upper limit of activity of radium equivalent $(370 \mathrm{~Bq} / \mathrm{kg}$ ).

\subsection{Equivalent activity of $\mathbf{R a}_{\mathrm{eq}}$}

The calculation of radium equivalent of the activity $\left(\mathrm{Ra}_{\mathrm{eq}}\right)$ is a value for comparison of the specific activities of the samples with different content of ${ }^{226} \mathrm{Ra},{ }^{232} \mathrm{Th}$ and ${ }^{40} \mathrm{~K}$. The distribution of ${ }^{226} \mathrm{Ra},{ }^{232} \mathrm{Th}$ and ${ }^{40} \mathrm{~K}$ in the soil is not uniform. The uniformity in regard to the exposure to radiation was defined in terms of the activity of radium equivalent $\left(\mathrm{Ra}_{\mathrm{eq}}\right)$ in $\mathrm{Bq} / \mathrm{kg}$ in order to compare the specific activity of the materials which contain different amounts of ${ }^{226} \mathrm{Ra},{ }^{232} \mathrm{Th}$ and ${ }^{40} \mathrm{~K}$. It is calculated by using the following ratio [6]

$$
\mathrm{Ra}_{\mathrm{eq}}(\mathrm{Bq} / \mathrm{kg})=\mathrm{A}_{\mathrm{Ra}}+1.43 \mathrm{~A}_{\mathrm{Th}}+0.07 \mathrm{~A}_{\mathrm{k}}
$$

$\mathrm{A}_{\mathrm{Ra}}, \mathrm{A}_{\mathrm{Th}}, \mathrm{A}_{\mathrm{k}}$-specific activities $(\mathrm{Bq} / \mathrm{kg}),{ }^{226} \mathrm{Ra},{ }^{232} \mathrm{Th}$ and ${ }^{40} \mathrm{~K}$, respectively. In order to be able to define $\mathrm{Ra}_{\text {eq }}$, it is assumed that $370 \mathrm{~Bq} / \mathrm{kg}^{226} \mathrm{Ra}$ or $259 \mathrm{~Bq} / \mathrm{kg}{ }^{40} \mathrm{~K}$, produce the same dosage strength on 1 meter above the soil surface. The value of the radium equivalent of the activity of $370 \mathrm{~Bq} / \mathrm{kg}$ corresponds to the maximum allowed dose for population of $1 \mathrm{mSv}$.

\subsection{Determination of specific activity}

\section{RESULTS AND DISCUSSION}

Table 1. Mean values of specific activities of ${ }^{226} \mathrm{Ra},{ }^{232} \mathrm{Th}$ and ${ }^{40} \mathrm{~K}$ in wheat samples

\begin{tabular}{|c|c|c|c|}
\hline & Specific activity* & ${ }^{*} \mathrm{~K}$ \\
\hline & ${ }^{26} \mathrm{Ra}$ & ${ }^{232} \mathrm{Th}$ & $328.15 \pm 2.00$ \\
\hline C1 & $0.58 \pm 0.4$ & $0.09 \pm 0.02$ & $166.70 \pm 2.79$ \\
\hline C2 & $0.55 \pm 0.11$ & $0.42 \pm 0.50$ & $144.15 \pm 1.33$ \\
\hline C3 & $0.70 \pm 0.09$ & $0.35 \pm 0.12$ & $371.12 \pm 2.66$ \\
\hline C4 & $0.53 \pm 0.11$ & $0.08 \pm 0.03$ & $201.86 \pm 1.58$ \\
\hline C5 & $0.62 \pm 0.17$ & $0.31 \pm 0.15$ & $115.54 \pm 2.39$ \\
\hline C6 & $0.44 \pm 0.09$ & $0.11 \pm 0.05$ & $327.86 \pm 2.12$ \\
\hline C7 & $0.61 \pm 0.33$ & $0.14 \pm 0.07$ & $328.10 \pm 1.80$ \\
\hline C8 & $0.69 \pm 0.30$ & $0.09 \pm 0.04$ & $120.47 \pm 1.90$ \\
\hline C9 10 & $0.54 \pm 0.13$ & $0.10 \pm 0.40$ & $349.11 \pm 2.58$ \\
\hline C11 & $0.69 \pm 0.03$ & $0.99 \pm 0.45$ & $155.02 \pm 2.00$ \\
\hline C12 & $0.50 \pm 0.24$ & $0.70 \pm 0.33$ & $295.97 \pm 1.00$ \\
\hline C13 & $0.71 \pm 0.20$ & $0.11 \pm 0.03$ & $129.50 \pm 2.75$ \\
\hline C14 & $0.55 \pm 0.15$ & $0.14 \pm 0.07$ & $326.27 \pm 2.51$ \\
\hline
\end{tabular}

*Mean value of measurements from wheat samples 
The represented results in the table are mean values from measurements performed on wheat samples taken from 14 different locations, with 3 samples from each location. The data show that the average value of activity of ${ }^{40} \mathrm{~K}$ in wheat is higher than the one of ${ }^{232} \mathrm{Th}$ and ${ }^{226} \mathrm{Ra}$ which is in accordance with the information in literature [7]. Furthermore, the use of potassium-containing fertilizer may also contribute for unequal distribution of ${ }^{40} \mathrm{~K}$ in the soil, therefore in wheat as well. However, ${ }^{40} \mathrm{~K}$ is the only radionuclide determined in a significant amount in the wheat samples in all locations. All other determined radionuclides which occur naturally are considered to have nominal concentrations. The results of the natural radioactivity were compared to the results for different countries from the world.

3.2 Rate of absorbed dose ( 2 tables)

In order to assess the equivalent average of annual effective dose imposed to the residents of each area, the external danger index was calculated for wheat samples.

Table 2. Radiometric results obtained for wheat samples

\begin{tabular}{|c|c|c|c|}
\hline & \multicolumn{2}{|c|}{ Specific activity $*^{*}$} & $\mathrm{Ra}_{\mathrm{eq}}$ \\
\hline & $\mathrm{D}(\mathrm{nGy} / \mathrm{h})$ & $\mathrm{H}_{\mathrm{eks}}$ & 23.67 \\
\hline $\mathrm{C} 1$ & 1.70 & 0.069 & 12.81 \\
\hline $\mathrm{C} 2$ & 7.50 & 0.036 & 10.84 \\
\hline $\mathrm{C} 3$ & 6.58 & 0.031 & 26.62 \\
\hline $\mathrm{C} 4$ & 15.87 & 0.078 & 15.19 \\
\hline $\mathrm{C} 5$ & 8.93 & 0.043 & 23.68 \\
\hline $\mathrm{C} 6$ & 5.11 & 0.025 & 23.78 \\
\hline $\mathrm{C} 7$ & 14.14 & 0.069 & 9.11 \\
\hline $\mathrm{C} 8$ & 14.15 & 0.069 & 23.07 \\
\hline $\mathrm{C} 9$ & 5.35 & 0026 & 12.35 \\
\hline $\mathrm{C} 10$ & 15.56 & 0.076 & 21.58 \\
\hline $\mathrm{C} 11$ & 7.25 & 0.035 & 9.81 \\
\hline $\mathrm{C} 12$ & 12.81 & 0.062 & 23.65 \\
\hline $\mathrm{C} 13$ & 5.76 & 0.028 & 0.069 \\
\hline
\end{tabular}

The mean value of absorbed dose for wheat samples is $9.62 \mathrm{nGy} / \mathrm{h}$ and it is lower than the global average value of $55 \mathrm{nGy} / \mathrm{h}$ [8]. The mean value of the index of radiation risk $\mathrm{H}_{\mathrm{eks}}$ is 0.05 which shows that in the surrounding of Skopje there is no significant radiation risk for the population. The values of the external danger index obtained in this study, regardless of the location, did not exceed the security limits, pointing out the insignificant danger for radiation which arises from soil radionuclides which are naturally present. From the very table one may see that the specific average for the radium equivalent $\mathrm{Ra}_{\mathrm{eq}}$ for wheat samples is from 9.11 $\mathrm{Bq} / \mathrm{kg}$ to 23.78 and it is below the maximum recommended limit, i.e. $370 \mathrm{~Bq} \mathrm{~kg}^{-1}$ [9]. This shows that the wheat samples in the Skopje region do not have a biological danger.

\section{DISCUSSION}

The values of specific activity and the calculated doses obtained in this study, regardless of the location, did not exceed the safety limits, pointing out the insignificant danger for radiation which arises from soil radionuclides which are naturally present. From the indicated above it follows that at a current level of radioactive contamination for wheat, it would not be necessary to take measures in regard to reduction of the radioactive contamination, considering that the values of the radioactive contamination, compared to the level of radiological contamination of natural origin are lower. Considering that the radioactive contamination in the animal body tissues primarily originates from the level of contamination of the used fodder as well as the water for lifestock watering, a preventive measure would be to control the radioactivity of the fodder during its use, that is, if possible it should have a lower concentration of radioactive isotopes which would not pose a danger to the animal organism. When choosing the methods of possible decontamination, one must pay attention to the half-life of the radioactive isotopes. These results can be used as reference values for current assessment of doses due to natural radioactivity in the surrounding of the city of Skopje. 


\section{LITERATURE}

[1] A.G. Kudryasheva, L. N. Shishkina, N. G. Zagorskaya, and A. I. Taskaev, Biochemical Mechanisms of Radiation Damage to Natural Populations of Mouse-Like Rodents, Nauka, St. Petersburg (1997)

[2] Vera Tome 2003.Soil-to-plants transfer factor for natural radionuclides and stable elements in a Mediterranean area. Journal of Environmental Radioactivity 65,161-17.

[3] 3.UNSCEAR Sources Effect and risks of Ionization Radiation ;United Nations Scientific Committe on the Effects of Atomic Radiations,Report to the General Assembly;United Nat ons,New York 1988.

[4] IAEA 295,Measurement of radionuclides in food and the environment, A guide book, Technical Report (1989)

[5] UNSCEAR 2000 Report to the General Assembly, with scientific annexes, Sources and effects of ionizing radiation, United Nations Scientific Committee on the Effects of Atomic Radiation, United Nations, New York, 2000].

[6] J. Beretka, P. J. Methew, Natural radioactivity of Australian building materials, industrial wastes and byproducts, Health Physics 48(1985) 87-95

[7] L.Saracević. Research on the impact of acute radioactive contamination of the soil on the effective equivalent dose and radiation risk of the population in the region of Sarajevo, Doctoral dissertation, Sarajevo 1990.

[8] 8.Al-Hamarneh and M. Awadallah, Soil radioactivity levels and radiation hazard assessment in the highlands of northerm Jordan, Radiat. Meas., 44, 102 (2009).

[9] 9. El-Aydarous, A., "Gamma Radioactivity Levels and Their Corresponding External Exposure of Some Soil Samples from Taif Governorate, Saudi Arabia", Global Journal of Environmental Research (GJER) Vol.1, No. 2, P: 49-53, (2007). 